\title{
OPTIMIZATION OF THE LIBRARY FOR SCHOOL LITERACY MOVEMENT
}

\section{Dwi Purwanti}

SD Negeri 3 Jatiluhur want_tea.7667@yahoo.com

\section{Article History}

accepted 30/09/2018

approved $12 / 10 / 2018$

published 30/10/2018

\section{Keywords}

library, school literacy movement

\begin{abstract}
The library in a school can be said to be the heart because it is a source of information for teachers and students. The library provides opportunities for students to expand and deepen their knowledge by reading various books.Thus, the library facilitates school residents to find information and knowledge needs and skills needed such as today, including literacy skills. The fact that exists today is that the use of libraries is less organized, the arrangement of books is less neat, and the number of inadequate books is an obstacle in increasing students' interest in reading activities. This study focused on: (1) what is the school literacy movement ?; (2) how to optimize the library for school literacy movements? The results of this study include: (1) school literacy movement is an effort or participatory activity involving all school residents to increase students' interest in reading;(2) optimization of the library carried out by making library activity programs, implementing library programs, and giving rewards related to library programs.
\end{abstract}

Social, Humanities, and Education Studies (SHEs): Conference Series https://jurnal.uns.ac.id/shes 


\section{PENDAHULUAN}

Hasil survei internasional, yaitu Progress in International Reading Literacy Study (PIRLS) pada 2011, serta Programme for International Student Assessment (PISA) pada 2009 dan 2012, menunjukkan bahwa keterampilan membaca siswa Indonesia masih berada pada peringkat bawah. Kondisi minat baca dan tulis bangsa Indonesia tergolong sangat memprihatinkan. Hal tersebut dapat dikutip dari hasil studi Most Littered Nation In the World yang dilakukan oleh Central Connecticut State University(dalam http://www.edukasi.kompas.com)pada Maret 2016 lalu menyatakan bahwa Indonesia menduduki peringkat ke-60 dari 61 negara soal minat membaca dan menulis. Keterampilan dalam membaca dan menulis disebut dengan istilah literasi.Fakta ini membuka mata kita semua bahwa kemampuan literasi siswa Indonesia masih rendah .

Sebagaimana kita ketahuiketerampilan literasi di era sekarang sangat penting agar siswa memahami teks secara analitis, kritis, dan reflektif. Berdasarkan Peraturan Menteri Pendidikan dan Kebudayaan Nomor 23 Tahun 2015, Menteri Pendidikan dan Kebudayaan Republik Indonesia mengeluarkan program pendidikan yang diberi nama Gerakan Literasi Sekolah. Program ini dilatarbelakangi oleh fenomena rendahnya keterampilan literasi yang membuktikan bahwa proses pendidikan belum mengembangkan kompetensi dan minat peserta didik terhadap pengetahuan. Gerakan literasi sekolah secara umum bertujuan untuk menumbuhkan budi pekertipeserta didik melalui pembudayaan ekosistem literasi sekolah yang diwujudkan dalam gerakan literasi sekolah agar mereka menjadi pembelajar sepanjang hayat.

Salah satu unit kerja yang menunjang proses ketrampilan literasi adalah perpustakaan. Perpustakaan juga dapat dikatakan sebagai jantung sekolah karena merupakan sumber belajar bagi guru dan siswa. Sebagai sumber belajar, perpustakaaan sekolah mempunyai tujuan untuk memenuhi kebutuhan informasi bagi masyarakat dilingkungan sekolah yang bersangkutan, khususnya para guru dan siswa. Seperti tertuang dalam undang-undang Republik Indonesia Nomor 43 tahun 2007 tentang perpustakaan.Perpustakaan berfungsi sebagai wahana pendidikan,penelitian, pelestarian, informasi, dan rekreasi untukmeningkatkan kecerdasan dan keberdayaan bangsa.

Surahman (2007) menyatakan bahwa perpustakaan sekolah dalam perannya di dunia pendidikan mempunyai fungsi sebagai: (1) pusat kegiatan belajar-mengajar untuk pendidikan seperti tercantum dalam kurikulum sekolah; (2) pusat penelitian sederhanayang memungkinkan parasiswamengembangkan kreativitas dan imajinasinya; (3) pusat membaca buku-buku yang bersifat rekreatif dan mengisi waktu luang (buku-buku hiburan); (4) pusat belajar mandiri bagi siswa

Dari pernyataan-pernyataan dapat ditegaskan bahwa seharusnya perpustakaan menjadi bagian integral dari sistem pembelajaran, bukan lagi menjadi 'pelengkap' sajabagi keberadaan sebuah sekolah.

Kenyataan yang kita jumpai hingga saat ini, perpustakaan di sekolah-sekolah belum dipandang penting untuk peningkatan kualitas pendidikan terutama literasi sekolah. Hal ini terlihat dari tidak berkembangnya perpustakaan di sekolah-sekolah. Berbagai problematika yang dihadapi oleh perpustakaan antara lain minimnya perhatian manajemen sekolah, keterbatasan anggaran perpustakaan, ketersediaan tenaga profesional pengelola perpustakaan, serta gedung dan perabot perpustakaan yang tidak mampu memberikan rasa nyaman bagi pemustaka ketika mengakses perpustakaan.

Menurut Rahman Saleh (http://www.merdeka.com)kondisi perpustakaan di Indonesia pada umumnya bahwa $95 \%$ dari sekitar 200.000 perpustakaan sekolah dan daerah di Indonesia tidak memiliki sarana dan prasarana memadai layaknya perpustakaan. Dari 130.000 sekolah di Indonesia ternyata baru ada 18\% diantaranya 
yang memiliki perpustakaan. Kemudian dari data Kementrian Pendidikan Nasional hingga tahun 2011, dari 143.437 SD, sebanyak 79.445 atau 55,39 persen sekolah tanpa perpustakaan. Di SMP sebanyak 39,37 persen sekolah (13.588 dari 34.511 sekolah) tanpa perpustakaan (http://edukasi.kompas.com).

Berbagai problematika yang dihadapi oleh perpustakaan sekolah serta minimnya jumlah perpustakaan sekolah merupakan kondisi perpustakaan sekolah pada umumnya. Berbagai problematika yang dihadapi oleh perpustakaan sekolah ini menyebabkan perpustakaan sekolah tidak mampu menjalankan tugasnya secara maksimal. Jika keadaan ini dibiarkan terus menerus maka gerakan literasi sekolah yang telah dicanangkan oleh pemerintah akan sia-sia belaka.

Melihat kenyataan tersebut maka perlu diaktifkan sebuah kegiatan yang menunjang suksesnya gerakan literasi sekolah, yakni optimalisasi perpustakaan. Untuk mengoptimalkan perpustakaan diperlukan ketrampilan dari seorang pustakawan yang selalu berusaha meningkatkan gerakan literasi sekolah. Pustakawan perlu terlibat secara langsung dalam Tim Literasi Sekolah. Tim literasi sekolah bisa terdiri dari guru, kepala sekolah dan pustakawan itu sendiri. Pustakawan bersama tim literasi membahas program optimalisasi perpustakaan untuk gerakan literasi sekolah

Sejalan dengan Lusia (2017) peranan perpustakaan dalam menunjang gerakan literasi sekolah dengan menyediakan area baca, sudut baca dan perpustakaan di sekolah sehingga siswa mengunjungi tempat-tempat tersebut. Selain itu juga mengadakan berbagai program kegiatan dalam menunjang gerakan literasi sekolah diantaranya pelatihan menulis, lomba cerpen dan artikel, storytelling, lomba mewarnai serta majalah dinding. Dengan demikian perpustakaan sekolah harus diberdayakan dengan maksimal melalui berbgaai program yang akan berdampak pada meningkatnya gerakan litersi sekolah.

Berdasarkan kebutuhan tersebut maka dalam kajian ini akan dibahas tentang optimalisasi perpustakaan untuk gerakan literasi sekolah. Fokus kajian ini berupa: (1) konsep gerakan literasi sekolah; (2) optimalisasi perpustakaan dalam gerakan literasi sekolah.

\section{PEMBAHASAN}

\section{Gerakan Literasi Sekolah (GLS)}

\section{a). Pengertian Gerakan Literasi Sekolah}

Literasi, dalam bahasa Inggris literacy, berasal dari bahasa Latin littera (huruf) yang pengertiannya melibatkan penguasaan sistem-sistem tulisan dan konvensi-konvensi yang menyertainya (Cooper dalam Wiedarti, 2016). Kegiatan literasi selama ini identik dengan aktivitas membaca dan menulis. Namun, Deklarasi Praha pada tahun 2003 menyebutkan bahwa literasi juga mencakup bagaimana seseorang berkomunikasi dalam masyarakat. Literasi juga bermakna praktik dan hubungan sosial yang terkait dengan pengetahuan, bahasa, dan budaya (UNESCO dalam Wiedarti, 2016). Dalam Deklarasi UNESCO menyebutkan bahwa literasi informasi terkait puladengan kemampuan untuk mengidentifkasi, menentukan, menemukan, mengevaluasi, menciptakan secara efektif dan terorganisasi, menggunakan dan mengomunikasikan informasi untuk mengatasi berbagai persoalan.

Literasi Sekolah dalam konteks Gerakan Literasi Sekolah adalah kemampuan mengakses, memahami, dan menggunakan sesuatu secara cerdas melalui berbagai aktivitas, antara lain membaca, melihat, menyimak, menulis, dan/atau berbicara.Dapat dikatakan Gerakan Literasi Sekolah merupakan sebuah upaya yang dilakukan secara menyeluruh untuk menjadikan sekolah sebagai organisasi pembelajaran yang warganya literat sepanjang hayat melalui pelibatan publik. Gerakan Literasi Sekolah dikembangkan berdasarkan sembilan agenda prioritas (Nawacita) yang terkait dengan 
tugas dan fungsi Kemendikbud, khususnya Nawacita nomor 5, 6, 8, dan 9. Butir Nawacita yang dimaksudkan adalah (5) meningkatkan kualitas hidup manusia dan masyarakat Indonesia; (6) meningkatkan produktivitas rakyat dan daya saing di pasar internasional sehingga bangsa Indonesia bisa maju dan bangkit bersama bangsabangsa Asia lainnya; (8) melakukan revolusi karakter bangsa; (9) memperteguh kebhinnekaan dan memperkuat restorasi sosial Indonesia (Faizah,2016:1).

Faizah (2016:2) memaparkan bahwa Gerakan Literasi Sekolah (GLS) merupakan kemampuan mengakses, memahami, dan menggunakan sesuatu secara cerdas melalui berbagai aktivitas, antara lain membaca, melihat, menyimak, menulis dan/ atau berbicara. Pengertian lain menyebutkan bahwa Gerakan Literasi Sekolah (GLS) merupakan sebuah upaya secara menyeluruh yang dilakukan sekolah sebagai organisasi pembelajar dan memiliki warga literat sepanjang hayat melalui pelibatan publik (Wiedarti 2016:2).

Dari pengertian di atas dapat disimpulkan bahwa pembiasaan literasi di sekolah membutuhkan kolaborasi dan keterlibatan publik yang aktif untuk menyukseskan lingkungan yang literat di sekolah. Pihak-pihak yang terlibat dalam Gerakan Literasi Sekolah diantaranya warga sekolah (peserta didik, guru, kepala sekolah, tenaga kependidikan, pengawas sekolah, komite sekolah, orang tua/wali murid siswa), akademisi, penerbit, mediamassa, masyarakat (tokoh masyarakat yang dapat merepresentasikan keteladanan, dunia usaha, dll.), dan pemangku kepentingan di bawah koordinasi Direktorat Jenderal Pendidikan Dasar dan Menengah Kementerian Pendidikan dan Kebudayaan.

\section{b) Tujuan dan Target pencapaian GLS di SD}

Faizah (2016:2) menyebutkan adapun yang menjadi tujuan umum dari GLS adalah menumbuhkembangkan budi pekerti peserta didik melalui pembudayaan ekosistem literasi sekolah yang diwujudkan dalam Gerakan Literasi Sekolah agar mereka menjadi pembelajar sepanjang hayat.

Selain itu tujuan khusus dari GLS adalah: (1) Menumbuhkembangkan budaya literasi di sekolah; (2) Meningkatkan kapasitas warga dan lingkungan sekolah agar literat; (3) Menjadikan sekolah sebagai taman belajar yang menyenangkan dan ramah anak agar warga sekolah mampu mengelola pengetahuan; (4) Menjaga keberlanjutan pembelajaran dengan menghadirkan beragam buku bacaan dan mewadahi berbagai strategi membaca.

Penerapan GLS dikembangkan dari Peraturan Menteri Pendidikan dan Kebudayaan Republik Indonesia Nomor 23 Tahun 2015 tentang Penumbuhan Budi Pekerti yang salah satu tujuannya adalah menumbuhkembangkan kebiasaan yang baik sebagai bentuk pendidikan karakter sejak di keluarga, sekolah, dan masyarakat.Gerakan literasi sekolah diprogramkan oleh pemerintah untuk menanggulangi bangsa Indonesia yang buruk dalam hal membaca.

Gerakan Literasi Sekolah di SD mempunyai target menciptakan ekosistem pendidikan di SD yang literat. Ekosistem pendidikan yang literat adalah lingkungan yang: (1) menyenangkan dan ramah peserta didik, sehingga menumbuhkan semangat warganya dalam belajar; (2) semua warganya menunjukkan empati, peduli, dan menghargai sesama; (3) menumbuhkan semangat ingin tahu dan cinta pengetahuan; (4) memampukan warganya cakap berkomunikasi dan dapat berkontribusi kepada lingkungan sosialnya; dan (5) mengakomodasi partisipasi seluruh warga sekolah dan lingkungan eksternal SD (Wiedarti,2016).

\section{c) Jenis-jenis Literasi}

Clay dan Fergusson (dalam Wiedarti,2016) menjabarkan bahwa komponen literasi informasi terdiri atas literasi dini, literasi dasar, literasi perpustakaan, literasi media, literasi teknologi, dan literasi visual. Dalam konteks Indonesia, literasi dini diperlukan sebagai dasar pemerolehan berliterasi tahap selanjutnya. 
Literasi Dini, yaitu kemampuan untuk menyimak, memahami bahasa lisan, dan berkomunikasi melalui gambar dan lisan yang dibentuk oleh pengalamannya berinteraksi dengan lingkungan sosialnya di rumah. Pengalaman peserta didik dalam berkomunikasi dengan bahasa ibu menjadi fondasi perkembangan literasi dasar.Literasi dasar secara umumdiawali dengan proses mendengarkan, berbicara, membaca, menulis, dan menghitung.Tujuan dari aktivitas-aktivitas tersebut adalah memperhitungkan, mempersepsikan, mengkomunikasikan, dan menggambarkan informasi yang diperoleh.

Sedangkan literasi perpustakaan adalah merupakan penerapan pemahaman tentang fungsi perpustakaan sebagai sarana untuk mendapatkan informasi.Gerakan literasi perpustakaan meliputi kegiatan memberikan pemahaman kepada siswa tentang jenis bacaan, yaitu bacaan fiksi dan nonfiksi. Siswa mampu mengenal perbedaan bacaan tersebut dan dapat memberikan contoh kedua bacaan tesebut. Selain itu, literasi perpustakaan juga mengenalkan adanya bacaan yang bersifat koleksi sebagai referensi dan yang bersifat periodik.Gerakan literasisekolah melalui perpustakaan juga mengenalkan kepada siswa bagaimana sistem pengkodean buku. Tujuan pengkodean adalah mempermudah siswa dalam pencarian sumber pustaka. Pengkodean tersebut meliputi pengklasifikasian, penggunaan katalog, dan pengindeksan.

Literasi selanjutnya adalah literasi media, yang sudah sangat dikenal dalam kehidupan sehari-hari. Literasi media merupakan pengetahuan tentang penggunaan media untuk menyebarkan informasi. Era sekarang banyak sekali jenis media yang dapat dimanfaatkan untuk gerakan literasi, misalnya media cetak, elektronik, dan digital. Media cetak terdiri atas surat kabar, majalah, tabloid, atau jurnal. Media elektronik meliputi radio dan televisi. Yang tidak kalah saat ini adalah media digital, yaitu internet yang sering digunakan sebagai sumber berita saat ini.Keberadaan media-media tersebut mendukung gerakan literasi sekolah. Siswa dapat menyampaikan kembali informasi yang didengar melalui media-media tersebut.

Literasi yang tidak kalah penting adalah literasi teknologi. Literasi ini juga perlu dipahami agar siswa dapat menggunakan teknologi dengan tepat dan beretika. Literasi teknologi yang dimaksud dalam hal ini adalah literasi berbasis kompuer. Siswa diajarkan untuk menggunakan komputer dengan tepat, meliputi cara menghidupkan, mematikan, dan menyimpan data. Siswa juga perlu diberi pemahaman untuk memanfaatkan teknologi dengan beretika. Artinya, siswa menggunakan teknologi untuk hal-hal positif.

Literasi yang terakhir adalah literasi visual. Pemahaman literasi visual meliputi pemahaman lanjut mengenai penggunaan media dan teknologiuntuk literasi. Semua informasi yang diterima secara visual, baik dalam bentuk media cetak maupun elektronik harus dikelola dengan baik.Berbagai manipulasi informasi harus diantisipasi dengan baik melalui kegiatan membaca secara cermat. Selain itu, diperlukan juga pemahaman untuk menyebarkan informasi yang benar dan patut.Berbagai jenis literasi tersebut saling berkaitan. Semuanya tidak dapat dipisahkan untuk mendukung gerakan literasi sekolah.

\section{d. Manfaat Gerakan Literasi Sekolah}

Manfaat gerakan literasi di sekolah adalah meningkatkan kemampuan literasi di semua mata pelajaran dengan menggunakan buku pengayaan dan strategi membaca di semua mata pelajaran. Menurut Komang dkk dalam e-Journal Jurusan Pendidikan Bahasa dan Sastra IndonesiaVolume: 7 No: 2 Tahun:2017 menyebutkan manfaat yang dirasakan dalam pelaksanaan Gerakan Literasi Sekolah, yakni (1) siswa menunjukkan kegemarannya terhadap karya tulis, seperti cerpen, puisi, novel, dan sebagainya sehingga siswa aktif dalam menghasilkan karya tulis, (2) kegiatan literasi dapat menciptakan kebiasaan membaca di kalangan siswa sekolah tersebut, (3) jumlah kunjungan ke perpustakaan yang semakin hari semakin meningkat, (4) 
guru merasa lebih mudah meminta siswa untuk membaca berbagai macam teks dalam pembelajaran Bahasa Indonesia karena siswa telah memiliki kebiasaan membaca yang baik, (5) guru merasa sangat terbantu dengan hadirnya fasilitas yang mendukung kegiatan literasi, seperti perpustakaan sekolah yang lengkap, pojok baca, perpustakaan maya, hingga perpustakaan kelas, (6) siswa dapat menyegarkan pikiran setelah seharianmembaca dan mempelajari buku pelajaran, (7) siswa dapat menambah wawasan tentang berbagai hal, seperti sastra atau apa pun yang disukai.

Sementara itu menurut Rahma (2016) manfaat literasi adalah: (1) menambah kosa-kata kita, (2) mengoptimalkan kerja otak, (3) menambah wawasan dan informasi baru, (3) meningkatkan kemampuan interpersonal, (4) mempertajam diri dalam menangkap makna dari suatu informasi yang sedang dibaca, (5) mengembangkan kemampuan verbal, (6) melatih kemampuan berfikir dan menganalisa, (7) meningkatkan fokus dan konsentrasi seseorang, (8) melatih dalam hal menulis dan merangkai kata-kata yang bermakna.

\section{Optimalisasi Perpustakaan}

a. Pengertian, tujuan, dan fungsi perpustakaan

Menurut UU No 43 Tahun 2007, perpustakaan adalah institusi pengelola koleksi karyatulis, karya cetak, dan/atau karya rekam secaraprofesional dengan sistem yang baku guna memenuhikebutuhan pendidikan, penelitian, pelestarian,informasi, dan rekreasi para pemustaka.

Pendapat lain perpustakaan adalah kumpulan bahan informasi yang terdiri dari bahan/book, materials dan bahan non book/ non book materials yang disusun dengan sistem tertentu, dipersiapkan untuk diambil manfaatnya, tidak untuk dimiliki sebagian keseluruhan (Lasa, 2007:19).

Berdasakan beberapa pendapat diatas dapat disimpulkan bahwa perpustakaan merupakanunit pengelola yang berisikan koleksi karyabaik berupa buku maupun bukan buku yang terletak dalam suaturuangan, diorganisasikan dengan sistem tertentu untuk diambil manfaatnya dan tidak dimiliki oleh para penggunanya untuk memenuhi kebutuhan pendidikan, peneitian, pelestarian, informasi dan rekreasi.

Perpustakaan bertujuan memberikan layanan kepadapemustaka, meningkatkan kegemaran membaca, sertamemperluas wawasan dan pengetahuan untukmencerdaskan kehidupan bangsa (UU No 43 Tahun 2007)

Secara umum perpustakaan sekolah diselenggarakan sebagai suatu perangkat kelengkapan pendidikan untuk bersama-sama dengan kelengkapan-kelengkapan yang lain guna meningkatkan ketaqwaan terhadap Tuhan Yang Maha Esa, kecerdasan dan keterampilan, mempertinggi budi pekerti dan mempertebal semangat kebangsaan dan cinta tanah air agar dapat menumbuhkan manusia-manusia pembangunan yang dapat membangun dirinya sendiri serta bersama-sama bertanggung jawab atas Pembangunan Nasional yang berasaskan Pancasila dan UUD 1945.

Secara khusus perpustakaan sekolah diselenggarakan untuk: (1) mengembangkan minat, kemampuan, den kebiasaan membaca, khususnyamendayagunakan budaya tulisan dalam segala sektor kehidupan, (2) mengembangkan kemampuan mencari dan mengolah serta memanfaatkan informasi, (3) mendidik murid agar dapat memelihara dan memanfaatkan bahan pustaka secara tepat dan berhasil guna, (4) meletakkan dasar-dasar kearah belajar mandiri, (5) memupuk minat dan bakat, (6) menumbuhkan apresiasi terhadap pengalaman imajinatif, (7) mengembangkan kemampuan untuk memecahkan masalah-masalah yang dihadapi dalam kehidupan atas tanggung jawab dan usaha sendiri.

Fungsi perpustakaan sekolah menurut Surahman (2007) adalah sebagai: (1) pusat kegiatan belajar-mengajar untuk pendidikan seperti tercantum dalam kurikulum 
sekolah; (2) pusat penelitian sederhanayang memungkinkan parasiswamengembangkan kreativitas dan imajinasinya; (3) pusat membaca bukubuku yang bersifat rekreatif dan mengisi waktu luang (buku-buku hiburan); (4) pusat belajar mandiri bagi siswa.

Suhendar(2005) menjabarkan bahwa perpustakaan sekolah mempunyai empat fungsi umum, yaitu edukatif, inovatif, kreasi, dan riset atau penelitian sederhana. Fungsi edukatif yaitu secara keseluruhan segala fasilitas dan sarana yang ada pada perpustakaan sekolah, terutama koleksi yang dikelolanya banyakmembantu para siswa sekolah untuk belajar dan memperolehkemampuan dasar dalam mentransfer konsep-konsep pengetahuan, sehingga di kemudian hari para siswa siswa memiliki kemampuan untuk mengembangkan dirinya lebih lanjut.

Fungsi informatif yaitu berkaitan dengan mengupayakan menyediakan koleksi perpustakaan yang bersifat memberi tahu akan hal-hal yang berhubungan dengan kepentingan para siswa dan guru. Melalui membaca berbagai bahan bacaan yang di sediakan oleh perpustakaan sekolah, para siswa dan guru akan lebih banyak tahu tentang segala hal yang terjadi di dunia ini.

Fungsi rekreasi yaitu dengan disediakannya koleksi yang bersifat ringan seperti surat kabar, majalah umum, buku -buku fiski, dan sebagainya, diharapkan dapat menghibur pembacanya di saat yang memungkinkan. Misalnya dikala sedang ada waktu senggang sehabis belajar seharian, bisa memanfaatkan jenis koleksi ini sehingga terhibur karenanya.

Fungsi riset yaitu koleksi perpustakaan sekolah bisa dijadikan bahan untuk membantu dilakukannya kegiatan penelitian sederhana. Segala jenis informatif tentang pendidikan setingkat sekolah yang bersangkutansebaiknya di simpan di perpustakaan ini sehingga dengan demikian,jika ada orang atau peneliti yang ingin mengetahui tentang informasi tertentu tinggal membacanya di perpustakaan.

\section{b. Program perpustakaan untuk gerakan literasi sekolah}

1) Integrasi perpustakaan dalam pembelajaran

Gerakan literasi di sekolah dihadapkan pada sejumlah tantangan. SDM atau pengelola perpustakaan merupakan kunci utama dalam kesuksesan gerakan literasi sekolah.Inovasi danide-ide kreatif dari pengelola perpustakaan akanmembawa perpustakaan menjadiperpustakaan yang berdayaguna dan juganyaman digunakan oleh murid maupun guru sehingga gerakan literasi sekolah berkembang. Untuk itu, pengelolaan perpustakaanmembutuhkan tenaga yang trampil mengenai seluk beluk perpustakaan,mempunyai ide-ide segar dan bekerja secara professional di perpustakaan. Untuk mengoptimalkan perpustakaan dalam rangka meningkatkan gerakan literasi sekolah mengharuskan pustakawan dan tim literasi membuat program kegiatan yang menunjang pembelajaran. Integrasi perpustakaan dalam pembelajaran diwujudkan dalam berbagai program diantaranya pojok baca kelas, peminjaman buku di perpustakaan, kunjungan perpustakaan, dan pencarian bahan pembelajaran.

Pojok baca merupakan pemanfaatan sudut ruang kelas sebagai tempat koleksi buku dari para siswa di tiap-tiap kelas. Penerapan program pojok baca diharapkan akan merangsang peserta didik untuk lebih gemar membaca dan memiliki daya pikir yang baik. Pemanfaatan sudut ruang kelas untuk dijadikan pojok baca juga sebagai penunjang dari perpustakaan sekolah. Selain peserta didik membaca, meminjam dan menjelajah sumber ilmu dari perpustakaan sekolah, peserta didik juga bisa memanfaatkan buku di kelas mereka masing-masing. Koleksi buku di pojok baca beragam seperti halnya koleksi buku di perpustakaan yaitu ada buku non fiksi dan fiksi.

Pembimbingan pada proses pojok baca adalah dengan memberikan dorongan kepada siswa untuk membaca buku pada pojok baca saat jam luang. Guru mewajibkan siswa yang ada di dalam kelas untuk membaca minimal 1 buku dalam jangka waktu tertentu, kemudian siswa diharuskan menuliskan judul buku dan maksud 
dari buku yang dibaca. Dengan adanya pojok baca diharapkan mampu menumbuhkan minat baca anak secara maksimal di lingkungan terdekatnya yaitu di dalam kelas.

Program selanjutnya adalah kunjungan ke perpustakaan. Pustakawan bekerjasama dengan guru mewajibkan kepada siswa untuk mengunjungi perpustakaan dengan membuat jadwal kunjungan. Namun demikian tidak dilarang jika siswa setiap hari berkunjung ke perpustakaan. Pustakawan memberikan berbagai macam kegiatan berkaitan dengan kunjungan perpustakaan diantaranya membaca dan menceritakan kembali, menonton cerita rakyat dengan membuat review, menggambar dan mewarnai. Dengan kegiatan ini diharapkan jumlah pengunjung akan semakin meningkat.

Setelah melakukan kegiatan kunjungan perpustakaan, dilanjutkan dengan program peminjaman buku. Dalam proses pembelajaran ditemukan materi tentang membuat sinopsis buku. Materi tersebut mengharuskan siswa untuk meminjam buku di perpustakaan dan membacanya. Kegiatan membuat sinopsis atau mereview buku sebaiknya dibudayakan sehingga siswa akan senang meminjam dan membaca buku. Guru mewajibkan siswa untuk mereview minimal 1 buku dalam 1 minggu. Petugas perpustakaan mencatat nama-nama siswa yang meminjam. Dari catatan peminjaman buku akan terlihat siapa saja yang sering meminjam buku di perpustakaan. Jika program ini dilakukan secara terus menerus maka akan terbentuk budaya baca tulis yang baik sehingga menunjang proses pembelajaran.

Dalam pembelajaran, mata pelajaran saling berkaitan satu dengan yang lainnya. Materi pembelajaran tidak semuanya ada di ruang kelas. Oleh karena itu guru memanfaatkan perpustakaan sebagai sumber informasi atau sumber yang menyediakan berbagai macam bahan pembelajaran. Peran perpustakaan sebagi pusat sumber belajar yaitu menyediakan berbagai informasi dan pengetahuan yang diperlukan dalam mengembangkan berbagai kompetensi yang diinginkan pada bidang studi atau mata pelajaran yang dipelajari. Oleh karena perpustakaan sebagai sumber belajar yang beraneka ragam diantaranya berupa bahan (media) pembelajaran, memberikan pembangunan yang positif dalam peningkatan pembelajaran dan gerakan literasi sekolah.

\section{2). Reward pengunjung perpustakaan}

Reward atau penghargaan adalah suatu cara yang digunakan untuk memberikan penghargaan kepada seseorang karena sudah mengerjakan suatu hal yang benar, sehingga orang yang menerima penghargaan lebih bersemangat dalam melakukan hal yang benar.penghargaan dapat diberikan dalam dua bentuk yaitu: (1) penghargaan verbal yang mengacu pada suatu tindakan spontan berupa pujian atas capaian peserta didik, (2) penghargaan nonverbal, berupa simbol atau gerakan anggota tubuh berupa acungan jempol maupun benda berupa piagam ataupun piala. Pemberian penghargaan bersifat mendidik, memotivasi, dan memperkuat perilaku dan mampu mendorong peserta didik mengambil inisiatif dan selalu bersemangat.

Reward yang dilakukan oleh pustakawan dalam gerakan literasi ini diberikan kepada siswa yang sering mengunjungi perpustakaan. Pustakawan mewajibkan siswa untuk mengisi daftar hadir kunjungan perpustakaan. Setiap bulan, pustakawan akan merekap daftar hadir kunjungan tersebut dan akan dikethui siswa yang paling sering berkunjung. Selain itu, reward diberikan kepada siswa yang paling sering meminjam buku dalam 1 bulan berjalan

Reward akan memberikan berbagai dampak positif, diantaranya: (1) Menambah semangat untuk terus mengikuti program kegiatan perpustakaan dalam rangka meningkatkan gerakan iterasi sekolah, (2) Bangga karena ketekunannya dihargai.Salah satu karakter yang dimiliki siswa adalah bangga pada diri sendiri. dengan rasa bangga kepercayaan pada diri sendiri tercipta. Dengan demikian, siswa semakin yakin jika apa yang ditekuninya berbuah manis. Hal ini akan berimbas pada 
prestasinya, (3) Memberi contoh/ teladan kepada siswa lain.Keteladanan itu sangat penting bagi orang lain. Apalagi keteladanan yang dapat menginspirasi. Dengan melihat temannya meraih prestasi, para siswa lain ingin melakukan hal sama. Hal ini berdampak positif bagi tumbuh kembang siswa lain, (4) Dikenal guru dan teman karena prestasi.Dikenal guru itu menyenangkan, apalagi dikenal karena prestasi. Tak kenal tak sayang. Siswa akan merasa senang jika dikenal oleh guru, (5) Menjadi sejarah dalam gerakan literasi sekolah.Prestasi yang diraih oleh siswa akan mengukir sejarah dalam dunia literasi di sekolah.

\section{3) Perlombaan tentang perpustakaan}

Untuk meningkatkan gerakan literasi sekolah, pustakawan dituntut menumbuhkan jiwa literat kepada siswa. Penumbuhan jiwa literat dapat dilaksanakan melalui berbagai perlombaan diantaranya lomba majalah dinding, lomba cipta dan baca pidato, lomba cipta dan baca puisi dan sebagainya. Lomba majalah dinding bertujuan untuk; (a) membina dan meningkatkan kemampuan kreativitas artistik siswa dalam bidang jurnalistik; (b) membina, mengembangkan dan meningktkan apresiasi siswa dalam bidang jurnalistik; (3) menyalurkan bakat dan minat siswa dalam bidang jurnalistik; serta (4) melatih kerjasama siswa dalam menyelesaikan pekerjaan dalam waktu terbatas.

Lomba cipta dan baca pidato dimaksudkan untuk melatih ketrampilan berbahasa. Keterampilan berbahasa meliputi empat aspek keterampilan yang saling mendukung yaitu menyimak, berbicara, membaca, dan menulis. Semakin terampil seseorang berbahasa, semakin cerah dan jelas pula jalan pikirannya. Keterampilan hanya dapat dikuasai dengan jalan praktik dan banyak latihan. Melatih keterampilan berbahasa berarti pula melatih keterampilan berpikir.

Puisi adalah bagian dari karya sastra. Proses menciptakan puisi memerlukan imajinasi dan kreativitas berbahasa. Oleh karena itu lomba cipta dan baca puisi termasuk dalam salah satu usaha meningkatkan gerakan literasi sekolah. Lomba cipta dan baca puisi merupakan bentuk apresiasi kepada pecinta karya sastra karena selain meningkatkan daya imajinasi siswa juga meningkatkan kualitas bahasa dan sastra. Puisi yang diciptakan siswa dapat dihayati dan diekspresikan dalam bentuk kemampuan membaca.

\section{SIMPULAN}

Gerakan Literasi Sekolah merupakan sebuah upaya yang dilakukan secara menyeluruh untuk menjadikan sekolah sebagai organisasi pembelajaran yang warganya literat sepanjang hayat melalui pelibatan publik. Pihak-pihak yang terlibat dalam Gerakan Literasi Sekolah diantaranya warga sekolah (peserta didik, guru, kepala sekolah, tenaga kependidikan, pengawas sekolah, komite sekolah, orang tua/wali murid siswa), akademisi, penerbit, media massa, masyarakat (tokoh masyarakat yang dapat merepresentasikan keteladanan, dunia usaha, dll.), dan pemangku kepentingan.

Perpustakaan merupakanunit pengelola yang berisikan koleksi karyabaik berupa buku maupun bukan buku yang terletak dalam suaturuangan, diorganisasikan dengan sistem tertentu untuk diambil manfaatnya dan tidak dimiliki oleh para penggunanya untuk memenuhi kebutuhan pendidikan, peneitian, pelestarian, informasi dan rekreasi.Untuk mengoptimalkan perpustakaan dalam rangka meningkatkan gerakan literasi sekolah dilakukan berbagai kegiatan sebagai berikut; (1) integrasi perpustakaan dalam pembelajaran; (2) reward pengunjung perpustakaan; dan (3) perlombaan tentang perpustakaan. 


\section{DAFTAR PUSTAKA}

Dewi,Rosita,2016.Peran perpustakaan Sekolah dalam Meningkatkan Literasi Informasi Siswa.Skripsi :UAD Yogyakarta

Faizah, Dewi Utama dkk. 2016.Panduan Gerakan Literasi Sekolah Di Sekolah Dasar.

Jakarta: Direktorat Jendral Pendidikan Dasar Dan Menengah Kementrian

Pendidikan Dan Kebudayaan

Ibrahim Bafadal. 2009.Pengelolaan Perpustakaan Sekolah.Jakarta:Bumi Aksara

Komang, dkk. 2017.Implementasi Program Gerakan Literasi Sekolah (GLS) di SMA

Negeri 1 Singaraja.e-Journal Jurusan Pendidikan Bahasa dan Sastra Indonesia

Volume:7 No:2 Tahun:2017

Kemendikbud.2016. Media Komunikasi dan Inspirasi:Jendela pendidikan dan Kebudayaan.Vol VI/ Oktober

Lasa.2007.Manajemen perpustakaan Sekolah. Yogyakarta:Pinus Book Publisher

Lusia Ega Andriana.2017.Peranan perpustakaan dalam menunjang penerapan gerakan literasi sekolah di SMA Muhamammdiyah 1 Yogyakarta. Skripsi:UIN Sunan Kalijaga Yogyakarta

Sinaga,Dian.2011.Mengelola Perpustakaan Sekolah.Bandung Bejana

Suhendar,Pawit.2005.Pedoman Penyelenggaraan Perpustakaan Sekolah.Jakarta: Kencana Prenada Media Group

Surahman, Arif.2007.Manajemen Perpustakaan Sekolah.Workshop untuk Kepala Sekolah, Guru dan Komite Sekolah di Ambarawa:Jawa Tengah

Wiedarti,dkk.2016.Desain Induk Gerakan Literasi Sekolah.Jakarta:Dirjen Dikdasmen http://www.merdeka.com/pernik/95-perpustakaan-di-indonesia-tak-representatifdiakses 25 September 2018

http://edukasi.kompas.com/read/2011/04/04/10332657/Sekolah.Terbelenggu.UU.Perpu stakaandiakses 25 September 2018

https://www.kata.co.id/Pengertian/Literasi/1791diakses 25 September 2018

http://www.mentawaikita.com/berita/1191/gerakan-literasi-sekolah-pentingkah.html http://www.merdeka.comdiakses 25 September 2018

http://edukasi.kompas.comdiakses 25 Sepetember 2018 